\title{
CENTINELAS DE LA PATRIA. REGIONALISMO VASCO Y NACIONALIZACIÓN ESPAÑOLA EN EL SIGLO XIX
}

\author{
SENTINELS OF THE MOTHERLAND. \\ BASQUE REGIONALISM AND SPANISH \\ NATIONALIZATION IN THE 19TH CENTURY
}

Coro Rubio Pobes

Universidad del País Vasco/Euskal Herriko Unibertsitatea

Recibido el 29-10-2015 y aceptado el 7-5-2016.

Resumen: Este artículo estudia las expresiones de patriotismo español y la idea de nación española presentes en el discurso del fuerismo vasco, hegemónico en las Provincias Vascongadas durante el siglo XIX. Su objetivo es analizar su significado y reflexionar sobre el papel que este discurso, expresión de un temprano regionalismo político, el primero en madurar en España, pudo desempeñar como mecanismo informal de nacionalización española, y a la vez constituir un sustrato cultural del que se nutriría el nacionalismo vasco finisecular.

Palabras clave: fuerismo, regionalismo, nacionalización española, identidad vasca, nacionalismo vasco, siglo XIX

\footnotetext{
Abstract: This article studies Spanish patriotism and the Spanish nationidea in the Basque Fuerism discourse, hegemonic in the Provincias Vascongadas during the 19th century. Its objective is to analyze the meaning of this discourse and to discuss whether this political regionalism - the first to appear in Spain - was an informal mechanism of Spanish nationalization, and, simultaneously, played a role as a cultural substratum, by which Basque nationalism would be nourished.
}

Key words: Fuerism, regionalism, Spanish nationalization, Basque identity, Basque nationalism, 19th century. 


\section{Centinelas de la Patria. Regionalismo vasco y nacionalización española en el siglo XIX ${ }^{1}$}

Una de las más sugestivas propuestas realizadas en el largo y fructífero debate historiográfico sobre el proceso de nacionalización española, formulada por M. Martí y F. Archilés hace ya unos años, llamó la atención sobre la importancia que mecanismos no formalizados (no dependientes de la acción del Estado) como la región tenían para la construcción y socialización de la idea de nación ${ }^{2}$. Con el fin de rebatir la influyente tesis de la débil nacionalización que había formulado en los noventa $\mathrm{B}$. de Riquer $^{3}$, el caso valenciano fue puesto de ejemplo de cómo la construcción de la región podía operar de eficaz vehículo de nacionalización española. El patriotismo regional, ejemplificado en el que desplegó el republicanismo castellonense finisecular, fue considerado instrumento privilegiado para la construcción y consolidación de la identidad nacional española ${ }^{4}$. Esta renovadora mirada sobre la región, los regionalismos y los patriotismos locales (formulada, no hay que olvidarlo, para analizar regionalismos y procesos de nacionalización del último tercio del siglo XIX) abrió nuevas posibilidades de análisis para el estudio de otros casos en España. Reflexionar sobre el caso del País Vasco, donde se desarrolló un temprano regionalismo que desplegó su discurso desde los años treinta del siglo XIX,

1 GIU 14/30.

2 Ferran Archilés y Manuel Martí, «La construcción de la nación española en el siglo XIX: logros y límites de la asimilación en el caso valenciano», Ayer, 35 (1999), pp. 171-190; Idem, «Un país tan extraño como cualquier otro: la construcción de la identidad nacional española contemporánea», en M. ${ }^{a}$ Cruz Romeo e Ismael Saz (eds.), El siglo XX. Historiografía e historia, Universitat de Vàlencia, Valencia, 2002, pp. 245-278; Idem, «La construcció de la regió com a mecanisme nacionalitzador i la tesi de la débil nacionalització espanyola», Afers, 48 (2004), pp. 265-307; Idem, «Una nació fracassada? La construcció de la identitat nacional espanyola al llarg del segle XIX», Recerques, 51 (2005), pp. 141-163. Un excelente recorrido por el debate sobre la construcción de la nación española: Ferran Archilés, «Melancólico bucle. Narrativas de la nación fracasada e historiografía española contemporánea», en Ismael Saz y Ferran Archilés (eds.): Estudios sobre nacionalismo y nación en la España contemporánea, Zaragoza, Prensas Universitarias de Zaragoza, 2011.

3 Borja de Riquer expuso su teoría en «La débil nacionalización española del siglo XIX», Historia Social, 20 (1994), pp. 97-114, recogiendo un primer planteamiento realizado en el I Congreso de Historia Contemporánea celebrado en Salamanca en 1992.

${ }^{4}$ Ferran Archilés, «Una nacionalización no tan débil: patriotismo local y republicanismo en Castellón (1891-1910)», Ayer, 48 (2002), pp. 283-312. 
y contribuir a una mayor comprensión de la relación entre regionalismos y nacionalismos son los objetivos de las páginas que siguen.

\section{El vasquismo fuerista, primer regionalismo español}

El fuerismo vasco alumbró el primer regionalismo español. Fue un regionalismo temprano, identificable ya en los años treinta y madurado plenamente antes del último tercio del siglo XIX; se adelantó por tanto sensiblemente a la cronología característica del resto de regionalismos españoles, que no madurarían hasta el último tercio de la centuria. Fue además un regionalismo atípico por su grado de afirmación del territorio como sujeto activo de derechos y su grado de elaboración de una personalidad etnocultural. Sus artífices fueron las élites fueristas, hegemónicas en el poder en las Provincias Vascongadas durante el reinado isabelino. Ellas concibieron una región vasca referida fundamentalmente al territorio de las tres provincias (Irurac Bat, las tres una) y reclamaron el reconocimiento político de su personalidad diferenciada, definida y defendida a través de un discurso sobre la identidad vasca. Ese discurso, comenzado a elaborar en los tiempos de la formación y consolidación del Estado liberal, expresó una concepción esencialista e historicista de la vasquidad, que cifró en los fueros, en la fe católica, en la historia y cultura propias (incluida la lengua euskara) y en el patriotismo vascoespañol sus principales referentes, como expliqué en un detenido estudio monográfico ${ }^{5}$. Ese estudio puso de manifiesto que el regionalismo cultural vasco del último tercio del siglo XIX del que habían hablado en su día A. Elorza y J. Corcuera, expresado en el Renacimiento Euskaro, era solo parte de un fenómeno más amplio y temprano que trascendía los límites culturales de aquél. Se trataba de un temprano regionalismo político, el vasquismo fuerista, que, como todo regionalismo, se concebía dentro de la nación española, pero que manifestó un patriotismo español específico, distinto del que trató de socializar el nacionalismo liberal.

El llamativo énfasis que el discurso fuerista puso en sus expresiones de patriotismo español ha sido interpretado sin embargo por algunos autores como manifestación y prueba del arraigo de la moderna identidad na-

5 Coro Rubio Pobes, La identidad vasca en el siglo XIX. Discurso y agentes sociales, Biblioteca Nueva, Madrid, 2003. 
cional española (e incluso hay quien apelando a él ha presentado al fuerismo como mero nacionalismo español $\left.{ }^{6}\right)$. Para dilucidar la cuestión, no basta con reparar en el número de afirmaciones de españolidad o en el énfasis puesto en ellas, como en ocasiones se ha hecho; hay que tratar de comprender cuál era el significado concreto de esas afirmaciones en el tiempo y el contexto cultural en el que fueron formuladas, qué concepto de nación española se manejaba en ellas, es decir, qué significado concreto tenía definirse como miembro de la nación española, identificarse como español, en ese determinado discurso. Solo así podremos determinar si el discurso regionalista del fuerismo isabelino fue vehículo de nacionalización española, si operó en el País Vasco la construcción de la región en la misma dirección nacionalizadora que en Valencia por ejemplo, si difundió, como afirman para este caso Archilés y Martí, «la aceptación del marco nacional y sus contenidos políticos y culturales» ${ }^{7}$.

Antes de entrar de lleno en la cuestión, es preciso dejar claras dos premisas clave de partida. En primer lugar que la región es, como ha recordado X. M. Núñez Seixas, una categoría tan imaginada como la nación $\mathrm{y}$, precisamente por ser una categoría construida, heterogénea como ella ${ }^{8}$. En segundo lugar, que no existe en todo el siglo XIX - ni antes ni después - la identidad española, una misma forma de identificarse como español ${ }^{9}$. No debemos por consiguiente hablar de identidad española, en singular, sino de identidades españolas, en plural. El primer liberalismo español formuló una de ellas, llenándola de contenido político y asimilándola a identidad nacional: en Cádiz quedó sentado que ser es-

${ }^{6}$ En ese énfasis, sobre el que Javier Fernández Sebastián llamó en su día la atención («La singularidad vasca antes del nacionalismo: identidad y diferencia», Revista de Libros, 86, mayo 2004, pp. 18-20), se ha apoyado exclusivamente Fernando Molina para afirmar que el fuerismo fue mero y «absoluto» nacionalismo español y que había arraigado en él el concepto de nación soberana del liberalismo (según ha sostenido en diversos textos desde La tierra del martirio español. El País Vasco y España en el siglo del nacionalismo, Centro de Estudios Constitucionales, Madrid, 2005, pp. 108-109).

7 Ferran Archilés y Manuel Martí, «Un país tan extraño...», p. 252.

8 Xosé M. Núñez Seixas, «Presentación», Ayer 64 (2006-4), pp. 11-17, cfr. p. 14.

9 Sobre la identidad española precontemporánea véase Pablo Fernández Albadalejo, Materia de España. Cultura política e identidad en la España moderna, Marcial Pons, Madrid, 2007. También los capítulos correspondientes de José Álvarez Junco, Mater dolorosa. La idea de España en el siglo XIX, Taurus, Madrid, 2001; de Juan Pablo Fusi, España. La evolución de la identidad nacional, Ediciones Temas de Hoy, Madrid, 2000; y de Antonio Morales Moya, Juan Pablo Fusi y Andrés de Blas (dirs.), Historia de la nación y del nacionalismo español, Galaxia Gutemberg-Círculo de Lectores, Madrid, 2013. 
pañol era equivalente a ser miembro de la nación española. Una nación soberana, monárquica, libre, independiente y católica. Y además trasatlántica ${ }^{10}$. Una idea de nación cuya función era legitimar la transformación de las sociedades fragmentadas de la monarquía hispánica tradicional en una moderna comunidad nacional que se identificara plenamente con el nuevo Estado-nación liberal, el cual se comenzó a edificar ofreciendo - como en otras partes de Europa - oportunidades de participación política, social, económica y cultural a sus miembros y prometiendo igualdad entre ellos (la nación concebida como «comunidad de recursos» igualitaria, en expresión de D. Langewiesche ${ }^{11}$ ). Pero la concepción gaditana no tardó en ser desplazada por la reelaboración moderada, la nación entendida como unidad del Estado (un Estado de sensibles menores dimensiones, perdido ya el imperio trasatlántico), que era también unidad católica, proyecto teleológico estatal y comunidad de costumbres políticas, sociales y religiosas ${ }^{12}$. Aunque ambas concepciones se legitimaban en la historia, la primera hizo de la libertad y la soberanía los referentes esenciales de la identidad nacional española, mientras que la nación de los moderados colocó en su lugar el monarquismo y el catolicismo ${ }^{13}$. Y esta concepción es la que se alzó como hegemónica en el siglo XIX y sustentó el proceso de nacionalización española que se

${ }^{10}$ La Constitución de 1812 definió a la nación española como «la reunión de todos los españoles de ambos hemisferios», entendiendo por españoles «todos los hombres libres nacidos y avecindados en las Españas», además de los extranjeros nacionalizados y los esclavos libertos. Fue una definición política, si bien no exclusivamente, pues el liberalismo gaditano «dibujó el esquema básico de formación de esa identidad - historia, lengua, costumbres...-, que más tarde, a partir de la década de 1830, comenzaría a adquirir plena entidad». M. ${ }^{a}$ Cruz Romeo, « ¿Y estos en medio de la nación soberana son por ventura esclavos? Liberalismo, nación y pueblo», Alcores, 7 (2009), pp. 13-37, cfr. p. 23.

11 Dieter Langewiesche, La época del Estado-nación en Europa, Universtitat de València, Valencia, 2012, p. 70 y ss.

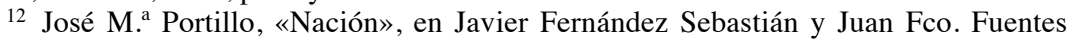
(dirs.), Diccionario político y social del siglo XIX español, Alianza, Madrid, 2002, p. 468 y ss; Javier Varela, «Nación, patria y patriotismo en los orígenes del nacionalismo español», Studia Historica-Historia Contemporánea, vol. XII (1994), pp. 31-43; Coro Rubio Pobes, «Patria y nación», en Juan Pro y Miguel Ángel Cabrera (coords.), La creación de las culturas políticas modernas (1808-1833), Marcial Pons y Prensas Universitarias de Zaragoza, Madrid, 2014, pp. 99-127.

$13 \mathrm{M}^{\text {a }}$ Cruz Romeo, «La tradición progresista: historia revolucionaria, historia nacional», en Manuel Suárez Cortina (ed.), La redención del pueblo: la cultura progresista en la España liberal, Universidad de Cantabria, Santander, 2006, cfr. p.109. 
desplegó en él. Con el tiempo, fue acentuando su contenido cultural, y colocando en su centro a la lengua castellana ${ }^{14}$.

Hubo sin embargo otras formulaciones de la identidad española y de la idea de nación española, distintas maneras de entenderlas, que no fueron hegemónicas ni dominantes. Entre ellas, las planteadas desde posiciones antiliberales, como las del absolutista leridano Lluís M. de Moixó, quien en los años treinta concibió la nación como ideal integrador, con capacidad movilizadora, en torno a un rey absoluto que encarnaría la identidad española; o el fraile carlista barcelonés Magí Ferrer, quien rechazó en los años cuarenta el igualitarismo que fundamentaba la concepción liberal de la españolidad, reivindicando la necesaria pluralidad de la nación y no reconociendo en ningún ente distinto del monarca el depósito de la soberanía ${ }^{15}$. También se plantearon concepciones alternativas de la nación española desde posiciones liberales, como la que a finales de los años cincuenta expresó el literato y político progresista barcelonés Víctor Balaguer, fundada en una concepción de España como «nacionalidad compuesta de diversas nacionalidades» ${ }^{16}$. El fuerismo vasco, ideología polifa-

${ }^{14}$ Sobre la creciente importancia de la lengua castellana en la identidad española Xosé M. Nuñez Seixas, «La(s) lengua(s) de la nación», en Javier Moreno Luzón y Xosé M. Nuñez Seixas (eds.), Ser españoles. Imaginarios nacionalistas en el siglo XXI, Barcelona, RBA, 2013, pp. 246-285. El salto de la reivindicación identitaria historicista a la lingüística en Xabier Zabaltza, Lengua, territorio y conciencia nacional en España (1839-1975), tesis doctoral, Universidad Pública de Navarra, 2003.

${ }^{15}$ Moixó expuso su concepción de nación en El príncipe y su pueblo, publicado en Barcelona en 1830, y Ferrer lo hizo en Las leyes fundamentales de la Monarquía Española, según fueron antiguamente y según conviene sean en la época actual publicada en Barcelona en 1843. Véase Jesús Millán, «La nación desde el antiliberalismo. Patria y monarquía en Lluís M. de Moixó», Alcores, 17 (2014), pp. 55-74; e Ídem, «El absolutismo en la época de los propietarios. La alternativa antiliberal de Magí Ferrer», en Emilio La Parra y Germán Ramírez (eds), El primer liberalismo: España y Europa, una perspectiva comparada, Biblioteca Valenciana, Valencia, 2003, pp. 155-184. Ferrer, explica Millán (p. 165), sostenía que los liberales habían introducido la centralización «bajo el especioso pretexto de que en España todos debemos ser españoles», habían anulado «el espíritu de provincialismo», de lo que resultaba la propagación de la anarquía y la opresión. Llega a decir que de haber conservado sus fueros los países de la Corona de Aragón, se habrían opuesto a la democracia, como habían hecho vascos y navarros.

${ }^{16}$ Como «una especie de "nación compuesta" que se inspiraba en el sistema "confederado" de la antigua Corona de Aragón», según explica Josep R. Segarra, «Liberales y fueristas. El discurso "neofuerista" y el proyecto liberal de nación española», en Carlos Forcadell y M. ${ }^{a}$ Cruz Romeo (eds.), Provincia y nación. Los territorios del liberalismo, Institución Fernando el Católico y Diputación de Zaragoza, Zaragoza, 2006, pp. 73-99, cfr. p. 98 . 
cética, dominantemente conservadora en tiempos del reinado isabelino (si bien no meramente asimilable a moderantismo, como suele hacerse), que constituyó uno de los vértices del triángulo político vasco de esa etapa (junto al liberalismo progresista y al carlismo), formuló otra concepción alternativa de la identidad nacional española, y expresó una forma específica de patriotismo español.

\section{Columnas del imperio, centinelas de la nacionalidad española, forjadores de la Patria}

Desde los orígenes mismos de la edificación del Estado liberal español, las élites políticas de Álava, Guipúzcoa y Vizcaya defendieron al unísono y con diversos argumentos la conservación de sus fueros. Afirmaron en primer lugar su esencia liberal, su análoga naturaleza con la Constitución gaditana; los presentaron después como modélico sistema de administración provincial que garantizaba el orden social y en nada menguaba la unidad constitucional del Estado; también como condición sine qua non para la consecución y mantenimiento de la paz en las tierras vascas (en la fase final de la primera guerra carlista); y argumentaron por último que los fueros eran el «modo de existir el país», el elemento definitorio de la esencia del pueblo vasco y expresión de su singularidad, de manera que no se podían suprimir aquéllos - explicaban - sin destruir gravemente a éste porque formaban parte esencial de su propia naturaleza. «Los fueros son [...] el modo de existir del país: son su vida social, sus hábitos, sus costumbres, su educación, sus afecciones predilectas, su impulso y movimiento preponderante, [...] son la animación y el alma de estas montañas», afirmaban las diputaciones vascongadas en noviembre de $1840{ }^{17}$. Al desarrollar este argumento, el discurso político se deslizó desde la defensa de la foralidad a la definición de la vasquidad, y se convirtió en un discurso identitario. Un relato sobre la identidad de los vascos, sobre lo que significaba ser y sentirse vasco, que incluyó entre sus principales referen-

17 Conferencia foral de 8 de noviembre de 1840. Puede verse el texto completo de esta conferencia y del resto de las que se citan en este artículo en Joseba Agirreazkuenaga (ed.), La articulación político-institucional de Vasconia: Actas de las Conferencias firmadas por los representantes de Álava, Bizkaia, Gipuzkoa y eventualmente Navarra (1775-1936). I. Colección de Textos Forales Vol. VI, Diputación Foral de Bizkaia, Diputación Foral de Gipuzkoa y Diputación Foral de Álava, Bilbao, 1995, cfr. p. 334. 
tes el doble patriotismo ${ }^{18}$ vasco y español; en realidad triple patriotismo, pues vigorosas identificaciones provinciales completaban el marco de referencias ${ }^{19}$. Un discurso elaborado por políticos fueristas, con el concurso de agentes culturales y religiosos, que acabó siendo asimilado también por las otras ideologías en concurrencia, liberales y carlistas vascos (aunque otorgando significado distinto a determinados referentes, como los fueros), y que definió a los habitantes de las Provincias Vascongadas - englobando ocasionalmente a Navarra - como un pueblo singular y diferenciado del resto de la Monarquía, incluso como nacionalidad diferenciada dentro de la nación española. Políticos e intelectuales no vascos también contribuyeron a difundir este discurso sobre la nacionalidad diferenciada, como el liberal moderado Alberto Lista, antiguo afrancesado que había residido un tiempo en Bilbao y que entre 1828 y 1830 había sido editor de La Gaceta de Bayona. Esto escribía en la Revista de Madrid en 1838:

Cualquiera que, después de haber recorrido las diversas provincias del reino, penetre en las vascongadas, observará necesariamente en sus campos un pueblo nuevo, diverso de los demás, con diversa lengua y costumbres, con un régimen casi patriarcal, con las ideas y sentimientos correspondientes a este régimen. [...] Esta sociedad singular, y distinta de las demás, no tiene más monumento que su existencia misma que se pierde en la noche de los tiempos. [...] En estas varias oscilaciones, en esta lucha casi continua de más de un siglo entre Castilla y Navarra, que obligó a los vascongados a pasar alternativamente de una dominación, o por mejor decir, de una confederación a otra no perdieron nunca su idioma, sus usos y costumbres [...]: en una palabra, conservaron su nacionalidad. ${ }^{20}$

18 La expresión doble patriotismo fue acuñada por Josep M. ${ }^{a}$ Fradera (Cultura nacional en una sociedad dividida. Cataluña 1838-1868, Madrid, Marcial Pons, 1992, ed. original en catalán de 1988), para subrayar precisamente la complejidad de la definición de las identidades regionales a partir de la revolución liberal, y alejarse del relato nacionalista, que sólo distingue identidades nítidamente definidas, sean españolas o catalanas, advirtiendo que no existen dos dobles patriotismos iguales.

19 Sobre esta triple adscripción véase Coro Rubio Pobes, «Los espacios identitarios del vasquismo decimonónico: provincia, país y nación», en Carlos Forcadell y M. ${ }^{a}$ Cruz Romeo (eds), Provincia y nación..., pp. 123-141.

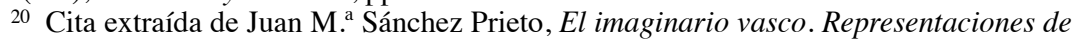
una conciencia histórica, nacional y política en el escenario europeo. 1833-1876, Eiunsa, Barcelona, 1993, p. 581. 
Si bien el concepto pueblo vasco/vascongado fue infinitamente más usual en el discurso del fuerismo que el de nacionalidad, éste alcanzó una notable repercusión al ser utilizado en 1864 por el alavés Pedro Egaña, el más influyente de los fueristas vascos, consejero de la reina María Cristina, en una conocida intervención en el Senado ${ }^{21}$. Egaña lo hizo puntualizando que esa nacionalidad formaba parte de otra englobante que era la española (la «gran nacionalidad», dijo), manejando así un concepto de nación que no estaba lejos del que había planteado desde Cataluña Víctor Balaguer, pero que no cabía en los estrechos límites del concepto que había hecho suyo el moderantismo, que solo distinguía en su seno provincias. Así de claro dejó esos límites el Gobierno en su contestación a la intervención de Egaña:

El Gobierno de S.M. no reconoce diferencia alguna legal ni política entre las provincias de España, entre todas las que componen la nacionalidad española; todas han venido de una u otra manera a componer esta nacionalidad, y todas tienen igual consideración e iguales derechos, conforme a la Constitución de la monarquía. [...] El Gobierno no conoce más que la nacionalidad española en la forma que yo demostraré. Otra nacionalidad, cualquiera que sea la forma en que se presente, el Gobierno la rechaza. Las provincias todas que componen la nacionalidad española, no deben temer en manera alguna que el Gobierno de S.M. menoscabe en lo más mínimo ninguno de sus derechos.

El discurso sobre la identidad vasca subrayó hasta el hastío la singularidad del pueblo vasco, afirmó una y otra vez que los habitantes de las Provincias Vascongadas constituían un pueblo diferenciado, un país singular. Pero a la vez insistió también una y otra vez en la identidad espa-

${ }^{21}$ Respondiendo a un comentario del senador andaluz Manuel Sánchez Silva, señaló: «Oigo que un Sr. Senador amigo mío se extraña de que use la palabra nacionalidad: claro es que al hablar en la época y momento que he hablado de nacionalidad, este Sr. Senador conocerá muy bien que, siendo aquellas provincias parte de España, no había de hablar de una nacionalidad distinta de la española; pero como dentro de esta gran nacionalidad hay una organización especial que vive con su vida aparte, por eso usaba la palabra nacionalidad al hablar de las Provincias Vascas. Conozco que tal vez hubieran sido más exactas las palabras organización o autonomía; de todas manera, si a S.S. no le parece conveniente la de nacionalidad, la reemplazaré desde luego con la de organización especial.». Sobre esta discusión véase Javier Pérez Núñez, «Autonomía y nacionalidad vasca. El debate sobre los Fueros vascos en el Senado de 1864», Studia Historica-Historia Contemporánea, vol. XII (1994), pp. 109-128. 
ñola de los vascos, en su patriotismo español, en su pertenencia a la nación española. «Nos llamamos vascongados porque no queremos renegar de nuestro nombre de pila; pero eso no quita que siendo vascongados seamos tan españoles [...] como el mejor español», explicó en el Senado Pedro Egaña el 16 de junio de 1864. El mejor español; así se conceptuaban, no como unos españoles cualesquiera sino como los mejores, de tal manera que este discurso sobre la españolidad era también un discurso sobre la diferencia y la singularidad vascas. No solo por concebirse a sí mismos como los españoles más genuinos, los últimos descendientes de los originarios pobladores de la Península Ibérica (tesis vascoiberista), que habían conservado además intacta la primitiva lengua nativa de los mismos, que es como se entendía entonces el euskera, sino por ser los más esforzados servidores de la patria, de la madre común España. Veamos tres elocuentes ejemplos:

Estas provincias, Señora, tienen un sentimiento y un pesar profundo de que en medio de tantos y tan abultados servicios se las juzgue como inútiles al resto de la nación y como un mero adorno territorial de la Corona. Las provincias Vascongadas no pueden convenir en esta idea: las provincias Vascongadas tienen dignidad nacional; se estiman en algo; y sus sentimientos de nobleza y de decoro se avergonzarían de no presentarse en el mapa político de la Monarquía como una verdadera columna que auxiliando a las demás contribuye a sostener la majestad, la fuerza y la grandeza del imperio español, y de la inmarcesible corona que ciñe las augustas sienes de Vuestra Majestad. [Representación a la reina de las Provincias Vascongadas acordada en conferencia foral de 13 de agosto de 1846, para solicitar que no se hiciera extensivo a ellas el sistema tributario general del Estado].

Mientras en el interior de la Península el soldado vasco aparece siempre en la vanguardia de los ejércitos de la Reconquista, como en las Navas de Tolosa, donde inicia la victoria más grande que han alcanzado las armas cristianas, el pueblo de que aquel soldado proviene, eterno centinela de la nacionalidad española, colocado como providencialmente en las puertas más peligrosas de la patria, vela y lucha en las cumbres del Pirineo y en las rocas del iracundo mar Cantábrico por la libertad e independencia de la patria, casi siempre amenazada por aquellas costas y fronteras. [Exposición a las Cortes de las diputaciones vascongadas el 16 de junio de 1876, durante la discusión de la Ley de fueros de 21 de julio]. 
[Los vascos], que siglos hacía que espontáneamente y bajo de pactos solemnes y formales se había[n] unido a la grande, a la heroica Nación española, contribuyeron desde los primeros tiempos de la reconquista, no a hacer la unidad nacional, sino a formar la Patria. [Intervención de Mateo Benigno Moraza en el Congreso el 8 de mayo de 1877].

Columnas del Imperio, centinelas de la nacionalidad española, forjadores de la Patria: no caben expresiones más encendidas de españolidad. Sin embargo, fue muy pronto cuestionada. Lo fue por aquellos liberales que consideraron inadmisible el mantenimiento de los fueros en el orden constitucional y que lo entendieron como un agravio comparativo para los demás territorios del Estado. En 1833, José Canga Argüelles, que había sido ministro de Finanzas en el Trienio, publicó su Diccionario de Hacienda dedicando una voz a las «Provincias Exentas» en la que arremetía contra los fueros afirmando que «nada es a la verdad más lastimoso para España que el resultado que producen las exenciones de las provincias vascongadas, provechosas a ellas y ruinosas a las demás», que «este monstruoso sistema, hace de las referidas provincias una nación estraña dentro de la España, siendo origen de su insubordinación», y que la percepción que tienen de sus fueros como emanados de la voluntad del pueblo «estableció una independencia que desliga esta parte del territorio español de los deberes y nexos sociales que reconocen los demás» ${ }^{22}$. Pero fue a partir de los años cincuenta cuando estos recelos arreciaron, coincidiendo con el avance del nacionalismo español y la pérdida del horizonte liberal-romántico de 1830 que había facilitado el encaje de los fueros en el orden constitucional ${ }^{23}$.

Entre las voces que se alzaron cuestionando la lealtad patriótica de los vascos destacó la del senador progresista andaluz Manuel Sánchez Silva, que desde 1849 desplegó una campaña de denuncia y deslegitimación de los fueros en el Parlamento y en la prensa; criticó al principal valedor de esos fueros en la Corte y el Gobierno, Pedro Egaña, por ser «defensor de los privilegios inconstitucionales vascongados» $\mathrm{y}$ «declarado enemigo de

22 José Canga Argüelles, Diccionario de Hacienda con aplicación a España, Madrid, Imprenta de D. Marcelino Carrero y Portocarrero, 1833-1834, 2 vols., cfr. vol. II, pp. 461-462.

${ }^{23}$ Sobre el significado de esta cesura para el debate sobre los fueros vascos, véase Juan M. ${ }^{a}$ Sánchez Prieto: «Constitución, fueros y democracia. Motivaciones, discursos y actitudes políticas con relación a la permanencia o abolición de los fueros vasco-navarros», Iura Vasconiae, 9 (2012), pp. 101-157. 
los demás españoles» ${ }^{24}$; y en la memorable sesión del Senado de 14 de junio de 1864 ya citada, en la que Egaña aplicó el concepto de nacionalidad a los vascongados, acusó a las tres provincias de volver la espalda a España y ser ingratas con ella ${ }^{25}$. Un opúsculo publicado ese mismo año, Crítica de los fueros de las provincias de Álava, Guipúzcoa y Vizcaya, escrito por Manuel García González, reproducía y glosaba los discursos de Sánchez Silva y Egaña, junto al del senador guipuzcoano Joaquín Barroeta Aldamar, lanzando durísimas diatribas contra los vascos. Les acusaba de ser «un pueblo ingrato», de que defendían «una pretendida supremacía, fuente perenne de males para la necesaria unidad de la Nación, y para su tranquilidad y reposo», de que «miran a España como suya para explotarla», y añadía que «todo el empeño de los vascongados es vivir sin más ley que su exclusiva voluntad» $\mathrm{y}$ «a costa de la sangre y los tesoros de todas las demás» provincias. «Los vascongados están haciendo el papel de señores, y los demás españoles son verdaderamente sus esclavos», llegaba a decir, y acusaba al «pensamiento de los fueristas» de ser «altamente sospechoso» de falta de patriotismo ${ }^{26}$. También, en 1864, la provincia de Santander, inmersa en una dinámica de rivalidad económica con Vizcaya, acusó a las Vascongadas de «lucrarse con sus fueros» a expensas de las demás provincias del reino ${ }^{27}$. Pocos años antes, en 1861, el abad de

${ }^{24}$ En su escrito Semblanzas de los 340 diputados a Cortes que han figurado en la legislatura de 1849 a 1850, Madrid, 1850. Citado por J. M. ${ }^{a}$ Sánchez Prieto, «Constitución, fueros...», p. 122.

25 «Pues bien: esas Provincias Vascongadas que nos deben su desarrollo; esas provincias de las que, valiéndome de una especie de figura retórica, puedo decir que son como un hijo a quien hemos alimentado, que hemos criado, que hemos llevado al estado de virilidad, y que nos vuelve la espalda y no quiere ayudarnos en nuestra vejez. [...] Nosotros miramos a los vascongados con el mayor aprecio; apenas hay época en que no haya habido vascongados en la carrera de las armas, en la literatura, en todos los puestos públicos. [...] ¿Qué quieren más? En compensación de todo esto, ¿qué recibimos nosotros? Una tenaz reticencia; reticencia por escrito, reticencia de palabras, que equivale a una amenaza embozada.»

${ }^{26}$ Crítica de los fueros de las provincias de Álava, Guipúzcoa y Vizcaya, Imprenta El Clamor Público, Madrid, 1864, cfr. p. 10, 13, 78, 112 y 298.

27 Fue en un escrito dirigido en abril de 1864 por los vecinos, comerciantes y propietarios de la provincia de Santander a las Cortes, publicado en el Boletín de Comercio, n ${ }^{\circ} 90$ de 22 de abril de ese año. Unos años antes, en 1839, el Ayuntamiento de Santander había dirigido una exposición a las Cortes admitiendo «el sacrificio de la concesión de los Fueros, modificados o no» como un mal menor que garantizara la paz, aunque recordando a las Cortes «que no debe regir en una nación regularmente gobernada, sino un sistema de rentas único, común a todos los gobernados, con unas mismas leyes orgánicas, aranceles, aduanas y tarifas». A las Cortes, s.d., Imprenta de Martínez. 
Santo Domingo de la Calzada, Justo Barbagero, había escrito una carta al ministro de Gracia y Justicia oponiéndose a la creación del Obispado de Vitoria - que recortaba la diócesis de Calahorra - en la que afirmaba que su «legislación especial es la que da a las tres provincias una especie de independencia, que hace muy precaria su unión con España si el vínculo político que las sujeta a la corona no estuviese fortalecido con el vínculo canónico que las estrecha y hace dependientes de Castilla», y que teniendo los vascongados «obispos de su habla, cabildo y párrocos de su habla, pastorales, sermones, libros en su habla, se aferrarán más y más en ella, tratarán de extenderla por los límites de las tres provincias, ganando el terreno perdido y haciendo de ella una lengua nacional», lo que incrementaría el amor a los fueros de los vascongados y contribuiría «a formar en España una nacionalidad distinta, y una base de separación política para los que más adelante quisieren invocar el principio de las nacionalidades ${ }^{28}$.

El empeño de las Provincias Vascongadas en defender el mantenimiento de sus fueros, entre ellos su forma particular de contribuir a la Hacienda y el Ejército sin sujetarse a las mismas normas y medida del resto del Estado, fue generando bien tempranamente recelos y dudas sobre su lealtad a España, que no lograban disipar aclaraciones como ésta de 1852:

Esas libertades, y el uso que de ellas hacen los que las gozan [...] ni chocan con los intereses generales de la Nación, ni interrumpen las buenas relaciones de amistad y armonía entre sus partes, ni exceptúan a los vascos de la obediencia que toda España presta a los mandatos del Soberano, ni trazan una línea divisoria que los separe de la familia española, ni los prive del alto honor de llamarse ellos también españoles. [...] Las instituciones vascongadas [...] son también, no lo olvide V.E. ni lo pierda de vista el Gobierno, el pedestal más sólido en que pudiera apoyarse la defensa de la patria ${ }^{29}$.

${ }_{28}$ Memoria sobre la reunión de las tres provincias vascongadas en un solo obispado, documento reproducido en Francisco Rodríguez de Coro, País Vasco, Iglesia y Revolución liberal, Caja de Ahorros de Vitoria, Vitoria, 1978, pp. 332-340.

29 Breves apuntes en defensa de las libertades vascongadas. Escrito leído a la llamada Comisión de arreglo de Fueros nombrada por el Sr. D. Juan Bravo Murillo en 1852, por el Exmo. Sr. D. Pedro de Egaña, Imprenta de J. E. Delmás, Bilbao, 1870, pp. 9 y 15 . 
Todos esos recelos prepararon el camino a un estado de la opinión pública española sumamente negativo hacia los fueros que acabaría estallando en 1876, pero que se pavimentó desde mucho antes, y que Antonio Cánovas sabría aprovechar para hacer valer su concepción de la unidad constitucional del Estado desmantelando los fueros vascos ${ }^{30}$.

No obstante, y a pesar de las reiteradas dudas que pudieran despertar en su tiempo, las expresiones de patriotismo español fueron omnipresentes en el discurso político del fuerismo, y se utilizaron, o más bien se intentaron utilizar, como movilizador social en las coyunturas bélicas de 1859 (Guerra de Marruecos) y 1868 (Guerra de Cuba), lo que puede llevar a pensar que no solo eran un recurso discursivo de las élites fueristas y que alguna base social debían de tener. Pero otra cosa es concluir que son evidente muestra del éxito (ya al finalizar los años cincuenta) de la moderna nacionalización española en las Provincias Vascongadas y afirmar que el sentimiento español que ahí se manifestaba en nada se diferenciaba de las expresiones de patriotismo español de otras provincias, consideradas prueba de la eficacia de dicha nacionalización. Antes de formular una conclusión así, es preciso plantearse qué tipo de sentimiento español era éste, si se trataba o no de una manifestación del moderno patriotismo liberal y de una idea liberal de nación española.

\section{EI doble patriotismo en el vasquismo fuerista}

Para dilucidar la cuestión planteada, no solo hay que constatar la machacona reiteración en el discurso político y en los medios de comunicación de la época de términos como nación o patria española y registrar las constantes y en muchas ocasiones exaltadas afirmaciones de españolidad, es preciso también tratar de desentrañar su significado, analizar la semántica de los términos empleados, decodificar el lenguaje. Y es preciso hacerlo considerando el conjunto del discurso en que se insertan esos términos, no aislándolos de él. Y no olvidando tampoco la praxis política que lo acompaña. Solo así podremos constatar que:

30 También suscitó recelos el fantasma del «provincialismo» desatado por el discurso neofuerista elaborado en Valencia, Aragón y Cataluña (véase Josep Ramón Segarra, «Liberales y fueristas...», p. 89), pero la guerra carlista de 1872-1876 disparó la desconfianza hacia los vascos. 
1. $\left.{ }^{\circ}\right)$ Cuando los fueristas apelaban a la nación española expresaban una idea veterorregimental de Monarquía, nación entendida como agregado plural de territorios a la Corona de Castilla, un nexo de unión que permitía albergar la diferencia y minimizar las tensiones que surgieran en torno a ella. Como ha explicado C. A. Bayly, al ser en el viejo orden el rey la fuente de autoridad antes que el pueblo, la diferencia entre «ellos» y «nosotros» era menos importante ${ }^{31}$. Cuando el Estado liberal sustituyó el lazo monárquico por un lazo nacional homogeneizador, que convirtió en problemática esa diferencia, las elites fueristas trataron de aferrarse a dicha concepción. Y a la práctica política derivada de ella; la interlocución directa con la Corona, considerada protectora de los fueros. Prolongaron así una praxis política propia del siglo XVIII, caracterizada por la búsqueda de acuerdos y compromisos entre la Monarquía y las élites provinciales, en la que los agentes en Madrid, los diputados en Corte, los personajes influyentes, y las redes sociales que éstos tejían desempeñaban un papel fundamental, y en la que la Corte era el centro neurálgico del $\operatorname{poder}^{32}$. Y lo hicieron tras comprobar que, desde que en Cádiz se desecharon posibles vías federalizantes, arraigaba en España una concepción del Estado bien lejana de lo que ellos consideraban modelos a seguir - el británico el primero de todos, al que se apeló en diversos discursos fueristas - que hubieran permitido, según entendieron, encajar sin problemas los fueros vascos.

Esta concepción de la españolidad es la que se expresó en las encendidas manifestaciones de patriotismo que hicieron las diputaciones vascongadas en las guerras de Marruecos y Cuba. No pueden entenderse bien - como ya señalé en otro estudio - aislándolas del discurso en que se insertan y sin reparar en que se asimila en él patriotismo español con lealtad a la Corona, e igualmente sin reparar en que el objetivo último que animó la contribución al esfuerzo de guerra que ofrecieron fue la voluntad de demostrar la utilidad del mantenimiento de los fueros vascos para la Monarquía, en concreto la utilidad del armamento foral, y fortalecer así los argumentos para su conservación. Ese esfuerzo se hizo con el explícito fin de hacer «recordar los útiles servicios que a la Corona de Castilla han prestado las Provincias Vasconga-

31 Christopher A. Bayly, El nacimiento del mundo moderno. 1780-1914. Conexiones y comparaciones globales, Siglo XXI, Madrid, 2010, p. 245.

${ }^{32}$ Sobre esta práctica política, Fernando Martínez Rueda, «La Monarquía borbónica y el Señorío de Vizcaya en la segunda mitad del siglo XVIII: ¿centro contra periferia?, Historia constitucional, 14 (2013), pp. 129-147, http://www.historiaconstitucional.com. 
das en los periodos más importantes y gloriosos de la historia nacional», buscando «elevar con provecho positivo de las instituciones forales el nombre Vascongado al grado de importancia y gloria en que, con motivos semejantes, le colocaron nuestros mayores, en defensa y esplendor de la Corona de Castilla» ${ }^{33}$. Ese patriotismo español no fue por tanto la expresión de una lealtad política de rango superior, último, que sería el característico de las identidades nacionales modernas, sino de un patriotismo de viejo cuño, de una idea de lealtad y servicio a la Corona veterorregimental, pero que resultó sumamente eficaz (hasta 1876, en que dejó de serlo). No era distinto del que se había manifestado antes de mediados de siglo: «Fíese, pues, a nuestros brazos la defensa del trono nacional. [...] el país ofrece solemnemente que perecerá en las gargantas de sus montañas quienquiera que ataque la independencia o el trono nacional: nosotros nos armaremos padre por hijo como manda el fuero», aseguraban las diputaciones vascongadas en una exposición a la Regencia de noviembre de $1840^{34}$. Se trataba de demostrar, en 1840, 1859 o 1868, que los vascos eran los más valientes y esforzados defensores de la Monarquía, como habrían puesto de manifiesto repetidamente a lo largo de los siglos desde su incorporación a la Corona de Castilla. Su situación fronteriza y, lo que es más importante, el sistema de armamento foral que permitía movilizar rápidamente a la población y formar los tercios en cuantas ocasiones fuera necesario, hacía de ellos - aseguraban - el más valioso baluarte para garantizar la independencia de la patria española.

Esto explica las encendidas expresiones de patriotismo español de aquellas élites que tomaron las decisiones en las mencionadas coyunturas bélicas. Pero ¿y las clases populares, esas que se habrían movilizado supuestamente embargadas de emoción patriótica? Pues esto es mucho más difícil de valorar, pero hay que reparar en que el llamamiento foral para el alistamiento de los 3.000 hombres prometidos al Gobierno en la Guerra de Marruecos de 1859, no fue respondido como cabría esperar de tan encendida exaltación patriótica (y generosa oferta); ante la extrema escasez de «voluntarios» para una guerra que aparecía como lejana y ajena, las autoridades tuvieron que autorizar el pago de primas en metálico y la re-

${ }^{33}$ Así lo expresaba el diputado general de Álava en una carta dirigida al diputado general de Guipúzcoa en septiembre de 1859. Una explicación más detenida en Coro Rubio Pobes, La identidad vasca ... pp. 155-168.

${ }^{34}$ Conferencia foral de 3 de noviembre de 1840. 
cluta de hombres nacidos fuera del país ${ }^{35}$. No pasó al parecer lo mismo en Navarra ${ }^{36}$.

2. ${ }^{\circ}$ ) El discurso del fuerismo (como el del foralismo del siglo XVIII ${ }^{37}$ ) afirmaba además que ese lazo nacional estaba originado por el pacto de incorporación de Allava, Guipúzcoa y Vizcaya a la Corona de Castilla (en realidad, pacto probado documentalmente solo para una parte de Álava, el territorio de la Cofradía de Arriaga), un pacto bilateral - argumentabanque obligaba a ambas partes, que comprometía a la primera en la conservación de los fueros y que no reconocía en ella potestad alguna para alterar unilateralmente sus términos. Así lo explicaba Pedro Egaña en 1852 a la Comisión de Arreglo de Fueros:

Es un problema resuelto en la historia que la unión de las Provincias a la Monarquía fue una entrega VOLUNTARIA Y CONDICIONAL: un contrato bilateral, obligatorio a ambas partes [...]. Los infrascritos se

35 Hay un estudio sobre este reclutamiento: Patxi Albisu Andrade, La Guerra de África, 1859-1860. La División Vascongada (el 2. ${ }^{\circ}$ Tercio), San Sebastián, 2011, cfr. p. 22. El análisis de los bertso paperak (composiciones poéticas populares en euskera impresas en hojas volantes) sobre esta guerra arrojarían más luz sobre la cuestión. Sobre el valor de esta fuente: Mikel Aizpuru, Ander Delgado y Maitane Ostolaza, «Pueblo, política y nación en el País Vasco (1833-1936)», en Mariano Esteban de Vega y M. ${ }^{a}$ Dolores de la Calle (eds.), Procesos de nacionalización en la España contemporánea, Universidad de Salamanca, Salamanca, 2010, pp. 329-354.

36 Ángel García Sanz ha afirmado que «todo indica que las muestras de patriotismo durante la guerra de África en esta provincia, que no se diferencian en nada de las de otras, se explican porque en ella el proceso de nacionalización española, como se deduce de la importancia numérica de los navarros en el ejército, estaba muy avanzado». En «Navarra en la guerra de África», Alcores 7, 2009, pp. 183-199.

${ }^{37}$ Los escritores foralistas del siglo XVIII defendieron ya esta idea. Pedro Fontecha y Salazar, en su Escudo de la más constante fe y lealtad (1748), defendió que Vizcaya era una comunidad política constituida previamente a la elección de su señor, y de su incorporación a la Corona de Castilla, a la que se unió como «provincia separada» y bajo un pacto que obligaba al rey de Castilla y señor de Vizcaya a mantener los fueros, entendidos como ley fundamental del territorio, sin poder alterarlos unilateralmente. Véase Fernando Martínez Rueda, «El fortalecimiento de la Diputación General de Bizkaia a finales del Antiguo Régimen (1750-1808)», en Joseba Agirreazkuenaga (dir.), Historia de la Diputación Foral de Bizkaia. 1500-2014, Diputación Foral de Bizkaia, Bilbao, 2014, pp. 163-196, cfr. pp. 169-170; y Jon Arrieta (ed.), Pedro Fontecha y Salazar. Escudo de la más constante fe, Universidad del País Vasco, Bilbao, 2015. Sobre otro de estos foralistas, José M. ${ }^{\text {a Portillo }}$ y Julián Viejo (eds.), Francisco de Aranguren y Sobrado. Demostración de las autoridades de que se vale el doctor D. Juan Antonio Llorente, Servicio Editorial de la Universidad del País Vasco, Bilbao, 1994. 
abstienen de alegar innumerables, escrituras, reales cédulas, provisiones de los Consejos y otros instrumentos auténticos, legales y solemnes que vienen todos a confirmar la primitiva libertad e independencia del país vascongado cuando las guerras de la reconquista; su voluntaria e incondicional incorporación después a la corona de Castilla; y la inmemorial existencia, transmisión no interrumpida y permanencia constante de los Fueros, cuya conservación reclaman. ${ }^{38}$

No era una singularidad este discurso pactista. También recurrió a él por ejemplo el regionalismo navarro, como ha señalado I. Iriarte. Desarrollado a partir de la segunda mitad del siglo XIX y plenamente en el último tercio, y generador de dos discursos identitarios distintos, el navarrismo y el nacionalismo vasco, aquel regionalismo recurrió a un historicismo pactista en defensa de la diferencia foral de este territorio, elaboró un relato nostálgico sobre el antiguo reino de Navarra que mantuviera la memoria de un pasado soberano y afirmara la identidad privativa de Navarra sin enfrentarse al concepto de España, y que sirviera para colocar al Estado en deuda con este territorio por el sacrificio hecho en aras de la unidad nacional al renunciar a esa independencia en 1841 (afirmando que de facto y de iure la independencia se había prolongado hasta esta fecha ${ }^{39}$. Pero la pervivencia de los fueros vascongados dotaba de un significado y alcance distinto al historicismo pactista vasco respecto del navarro, y de cualquier otro; aquí no había nostalgias del pasado, sino una tradición viva, que facilitaba argumentar la conservación de la - así afirmada - originaria y secular independencia, y sostener que la - así entendida - vigencia del pacto por los fueros condicionaba el lazo con la Monarquía.

El patriotismo español del discurso fuerista era por tanto expresión de reconocimiento, agradecimiento y lealtad a una Corona de Castilla que había jurado respetar los fueros en el momento de la -insistentemente reiterada - incorporación pactada a ella de cada uno de los territorios vascongados, y que, transformada en Monarquía constitucional, se

${ }^{38}$ Breves apuntes en defensa de las libertades vascongadas: escrito leído a la llamada Comisión de Arreglo de Fueros nombrada por el Señor Don Juan Bravo Murillo en 1852, Imprenta de Juan E. Delmás, Bilbao, 1870.

39 Argumentaban que en 1512, cuando Fernando el Católico conquistó Navarra, los navarros solo se entregaron a él con condiciones, reconociéndolo como súbditos, no como vasallos, y bajo el compromiso de respetar sus fueros, es decir, bajo pacto. Iñaki Iriarte, «La provincia foral. La nostalgia de la independencia», en Carlos Forcadell y M. ${ }^{\text {a Cruz Ro- }}$ meo (eds.), Provincia y nación..., pp. 143-158. 
había comprometido en un nuevo pacto bilateral - según entendía el fuerismo - mediante la Ley de 25 de octubre de $1839^{40}$. Pero ese patriotismo se expresaba condicionado al mantenimiento de ese pacto, al compromiso de conservación de los fueros. Uno de los documentos que con más fuerza reflejó esta idea es la carta que en abril de 1837, en plena primera guerra carlista, envió un militar guipuzcoano, el coronel de infantería Pascual Churruca, con el respaldo de la Diputación de Vizcaya, a los miembros de la comisión parlamentaria especial encargada de elaborar un proyecto de nueva constitución (Agustín Argüelles, Salustiano Olózaga y José Gómez Acebo), en la que pedía la supresión de un artículo sobre unificación de leyes en todo el Estado. Churruca, que se declaraba en la carta español y guipuzcoano, «amante a la vez de la libertad de España y de las Constituciones de mi nativo suelo» y que utilizaba las expresiones «nuestra patria» y «nuestra nación» para referirse a España, «nuestra España», decía en ella:

Los principios de igualdad y de derecho y de cargas que en los Gobiernos representativos deben siempre observarse para las provincias de una misma nación, no son aplicables a las de Vizcaya, que se hallan agregadas a España condicionalmente y sin menoscabo de su independencia en todo lo concerniente a sus derechos políticos, a su administración y gobierno [...]. Este pueblo idólatra de sus venerandas instituciones y antigua libertad, o perecería entero o abandonaría para siempre España en medio de su desesperación primero que consentir en la pérdida de tan queridos objetos. ${ }^{41}$

La agitación de este espantajo separatista fue no obstante una rareza en el discurso fuerista, que no puso en cuestión la unidad de España, pero que apuntaló su vinculación afectiva a ella en los fueros y en su conservación.

40 Así lo explicó Joaquín de Barroeta Aldamar en el Senado en junio de 1864: «Yo considero, señores, y muy altos jurisconsultos consideran como yo la ley de 25 de octubre de 1839 como paccionada, y esta circunstancia le hacía decir a uno de los más ilustres jurisconsultos que hay hoy en Madrid, que dicha ley era constitucional, y así lo creo también, porque procede de un contrato bilateral, de un contrato respetable, y más respetable aun para una nación de caballeros como es la nación española». Esta lectura fue reiteradamente denunciada y negada por progresistas como Sánchez Silva.

${ }^{41}$ Carta del coronel de infantería Pascual de Churruca a los señores D. Agustín de Argüelles, D. Salustiano Olózaga y D. José Gómez Acebo sobre los fueros, Bilbao, 6 de abril de 1837, Imprenta de Vda. de Luis Tasso, Barcelona, 1919, cfr. pp. 18 y 21-22. 
3..$\left.^{\circ}\right)$ Hay que prestar también atención a la compleja cuestión de la idea de soberanía. El primer concepto liberal de nación hizo de la soberanía su eje definidor, y aunque la reelaboración moderada del mismo incrementó su carga cultural, el concepto se mantuvo asociado a esa idea ${ }^{42}$. Difícilmente se puede considerar que arraigaron estos conceptos entre quienes defendieron la plena conservación de la capacidad de los territorios vascos para regirse por sus propias leyes forales, entre quienes negaron al Parlamento, representante de la soberanía nacional, potestad para modificar o suprimir unilateralmente el régimen foral. Hubo en las Provincias Vascongadas un sector social que sí los asumió plenamente, liberales progresistas combativos con los fueros y el poder oligárquico que se amparaba en ellos, liberales que, como Joaquín M. Ferrer, tuvieron un importante protagonismo en la política estatal desempeñando altos cargos de la administración del Estado, pero no quienes elaboraron y difundieron el vasquismo fuerista. Especialmente quienes entre ellos defendieron con vehemencia la conservación intacta de la originaria independencia de los territorios vascos. La carta que en 1837 escribió Pascual Churruca decía:

[...] aquí el pueblo ha sido siempre el único soberano; aquí los hijos de la tierra han ejercido con la mayor lasitud sus derechos políticos; aquí las leyes y los fueros han emanado del pueblo; aquí los Reyes de España no mandaron jamás como en otras provincias ni tuvieron autoridad para dictar leyes como en ellas. Estas Repúblicas se hallan agregadas a la corona de España sin perjuicio de sus fueros. Los reyes de Castilla no son soberanos de estas tierras, ni ejercieron jamás en ellas autoridad de tales. La soberanía residió siempre en las Repúblicas, en su pueblo; de ellas emanaron esas leyes, esos fueros inmemoriales que no son ni concesiones, ni mercedes de ningún monarca. [...] Dígaseme ahora en buena fe con qué derechos, con qué razón pueden las Cortes pretender la abolición de los fueros de este pueblo, en todos tiempos independiente, en todos tiempos libre, en todos tiempos bien gobernado. ${ }^{43}$

Se ha llegado a afirmar que el discurso fuerista «insistió hasta el hastío en la exaltación insistente y superlativa de España como nación, es de-

${ }^{42}$ Y progresivamente alejado del concepto de patria, como señala Juan Fco. Fuentes, «Conceptos previos: Patria y nación en los orígenes de la España contemporánea», en Antonio Morales Moya, Juan Pablo Fusi y Andrés de Blas (dirs.), Historia de la nación..., pp.169-196, cfr. p.188.

${ }^{43}$ Carta del coronel de infantería D. Pascual de Churruca,... pp. 10-11. 
cir, como sujeto histórico soberano ${ }^{44}$. Está más que claro que el discurso vasquista del fuerismo albergó un fundamental patriotismo español, pero nada en él permite establecer ese «es decir». Las fuentes documentales ponen de manifiesto que, a la par que se loaba a la nación española, en lo que se insistía de forma superlativa en ese discurso era en la teoría pactista, y en la negación de la capacidad del Parlamento para alterar el statu quo respaldado por la Ley de 25 de octubre de 1839, entendida por el fuerismo como nuevo pacto que reconocía la legalidad constitucional de los fueros vascos. No podían por tanto reconocer los fueristas en la nación española un sujeto histórico soberano porque hubiera significado reconocerle plena capacidad para disponer de los fueros vascos. Y todo el discurso fuerista estaba edificado precisamente para negar esto.

Incluso el liberalismo progresista vasco, que en los años cincuenta se hizo abiertamente defensor de los fueros (de unos fueros ya dentro de la legalidad constitucional, y convenientemente modificados), más exactamente una parte del progresismo vasco (pues quedan fuera quienes orientaron su vida política al servicio del Estado), acabó asimilando el discurso sobre la conservación de la antigua soberanía vasca. Víctor Luis Gaminde, que había sido uno de los más significados ideólogos del progresismo vizcaíno, escribió esto en 1852:

Las Provincias Bascongadas [...] son y fueron estados no de hoy sino durante el transcurso de siglos, y si la nacionalidad radica esencialmente en el ejercicio de ciertas formas propias y en la celebración de tratados a que no son admitidas las que no sean potencias, las tres provincias hermanas lo son incontestablemente. Las Provincias Vascongadas extraerán de sus archivos documentos irrecusables, que prueban como la luz del día, que en el interior trataron con sus reyes como de nación a nación, y en el exterior con los soberanos de naciones de primer orden, como de igual a igual. ${ }^{45}$

No se puede por consiguiente afirmar que las expresiones de patriotismo español de los fueristas significaban la aceptación de la idea de Es-

${ }^{44}$ Fernando Molina, La tierra del martirio..., p.108.

45 Impugnación al proyecto llamado arreglo de los fueros de las provincias bascongadas, presentado por la comisión del gobierno a las de las mismas provincias, por Víctor Luís Gaminde, Imprenta de Juan E. Delmás, Bilbao, 1852. Ha sido editado por José M. ${ }^{a}$ Portillo, Costumbre democrática. Debates liberales sobre fueros vascos, Universidad del País Vasco, Bilbao, 2013. 
paña como sujeto histórico soberano. Negar esto no significa en absoluto proyectar en el fuerismo planteamientos del posterior nacionalismo aranista; lo que sostengo es que su concepción de la soberanía hay que entenderla en su tiempo y contexto, y es un rasgo arcaizante. El fuerismo combinó rasgos arcaizantes y rasgos de modernidad, pero no fue desde luego un criptonacionalismo vasco ${ }^{46}$. Tampoco nacionalismo español.

4. $\left.{ }^{\circ}\right)$ Para comprobar si opera en el País Vasco la construcción de la región como eficaz instrumento para la interiorización de la moderna identidad nacional española, para observar si difundió en él la aceptación del marco nacional y de sus contenidos políticos y culturales de que hablan Archilés y Martí, es necesario examinar qué referentes y símbolos compartidos pudieron existir entre el discurso nacionalista español del liberalismo moderado y el discurso identitario del fuerismo, que no fue el único pero sí el hegemónico y dominante en las Provincias Vascongadas. Dos saltan a la vista, el catolicismo y el monarquismo, pero hay que reparar en que tienen significados distintos en cada discurso, en cada respectivo contexto de significación. El catolicismo, que es uno de los referentes fundamentales del código de identidad vasca, se utilizó en el discurso fuerista para afirmar la singularidad del pueblo vasco, su superioridad e incluso su carácter de pueblo elegido, es decir, como elemento diferenciador (aunque no lo fuera). La tesis del primitivo cristianismo de los vascos hablaba de un monoteísmo sin mezcla de paganismo desde la noche de los tiempos y de una conversión inmediata a la fe cristiana desde su primera predicación, fe a la que se atribuía una protección benéfica sobre los fueros, que se habrían conservado gracias a la protección divina: «El país vascongado es el único en el mundo que permanece siempre incólume entre el cúmulo de ruinas que cubren el universo. Bendito sea el Señor, una y mil veces bendito, por haber elegido pueblo tan reducido y pobre para ejemplo tan grandioso», afirmaba en 1858 el diputado a Cortes por Alava Ramón Ortiz de Zárate. El monarquismo por su parte tiene en el discurso vasquista, como ya he señalado, esa dimensión pactista y de expresión de agradecimiento por la conservación de la foralidad. En cuanto a los héroes nacionales españoles, el lugar preeminente de los Pelayos, Campeadores, Guzmanes, Gonzalos de Córdoba, lo ocupan en el discurso vasquista los Jaun

46 Otra cosa es etiquetarlo de prenacional o protonacional, que no es sinónimo de criptonacionalista. Ahora bien, estas etiquetas no deben ser sino meros instrumentos analíticos que ayuden a subrayar conexiones, pero que si no se entienden así -y en el estudio del caso vasco hay quien no lo entiende, y las maneja en sentido teleológico- es mejor evitar. 
Zurias, Elcanos, Oquendos..., héroes vascos que encarnaban la idea de autogobierno (Jaun Zuria por ejemplo, un caudillo legendario, elegido por los vizcaínos primer señor de Vizcaya, un mito surgido en el Edad Media), singular fe católica (Ignacio de Loyala) y esforzado servicio de los vascos a la Corona española (entre otros, los dos marinos citados, que también, en otro contexto discursivo y por tanto con otro significado, se incluyeron en el panteón nacionalista español $)^{47}$. Y el lugar de las gestas de Sagunto o Numancia - el lugar preeminente, no estoy diciendo que no aparezcan mentadas - , el de la resistencia vascocántabra a las invasiones extranjeras o el de la batalla de Arrigorriaga (una leyenda del siglo XV que narra el enfrentamiento en el siglo IX entre las tropas leonesas y las vizcaínas lideradas por Jaun Zuria para defender la independencia de Vizcaya). Es decir, existió un imaginario propio, que expresaba el patriotismo vascoespañol, que hablaba de los servicios de los vascos a la defensa de la Corona, pero a la vez afirmaba la singularidad de su pueblo a lo largo de la historia y su esforzada defensa de la (mítica) independencia de su territorio. No es éste propiamente el imaginario castellanista (cuando menos, no exclusivamente), ni tampoco el estereotipo romántico andalucista que desde mediados del XIX se convirtió en quintaesencia de lo español ${ }^{48}$. Y aunque la presencia de un imaginario propio no es un rasgo singular del territorio vasco, sí lo es la fuerza de ese imaginario, su contenido y su contexto discursivo.

Archilés y Martí han señalado que la construcción de la identidad nacional española no debe ser entendida solo en clave de definición política sino que «se hizo sobre un modelo cultural basado, al menos, en dos rasgos centrales: la lengua castellana y una argumentación historicista», y que la crisis del 98 y la pérdida definitiva del imperio acentuó «el carácter acusadamente cultural de la identidad española contemporánea», agu-

47 Algunos de estos héroes formarán parte del panteón nacionalista del aranismo, en un contexto distinto de significación, y otros serán desechados. Véase Coro Rubio y Santiago de Pablo, «Before and after the nation: Basque patriotic heroes, 1834-1939», Studies on National Movements, 3 (2015), http://snm.nise.eu/index.php/studies/article/view/0302a.

${ }_{48}$ Bien por aceptación del estereotipo fabricado desde fuera, desde Europa, según Joaquín Álvarez Barrientos («Aceptación por rechazo. Sobre el punto de vista extranjero como componente del costumbrismo», en Jean René Aymes, y Serge Salaün (eds.), Le métissage culturel en Espagne, Presses de la Sorbonne Nouvelle, París, 2001, pp. 21-36), o bien como resultado de un proceso de reelaboración interna, según explica Xavier Andreu Miralles («iCosas de España! Nación liberal y estereotipo romántico a mediados del siglo XIX», Alcores 7, 2009, pp. 39-61, cfr. p.50). 
dizándose, «haciéndose acusadamente explícita, una forma de identidad basada en la lengua y cultura castellanas ${ }^{49}$. En el país vasco, desde que en el siglo XVI las élites adoptaran el castellano como lengua de prestigio social, cultura y poder, se configuró un universo lingüístico diglósico en el que esta lengua ocupaba el espacio administrativo y político, mientras que el universo campesino y popular era territorio del euskera ${ }^{50}$. Pero en el discurso vasquista la lengua que tiene fundamental dimensión identitaria es el euskera, no el castellano, precisamente porque esta última no constituye ningún elemento de singularidad $-\mathrm{y}$ ese discurso se pivota sobre la idea de la singularidad - . No aparece el castellano valorado en él como el euskera, lo cual no significa que no se entendiera y sintiera como una lengua propia, al menos entre las élites. De hecho, en 1873 fue fundada en Vitoria, por Fermín Herrán, una Academia Cervántica Española. Desde ella se combatió contra la utilización de Cervantes como argumento de autoridad para lanzar críticas hacia los vascos. Julián Apraiz, primer director del centro, lo presentó incluso como defensor del euskera y publicó en 1881 Cervantes vascófilo o sea vindicación de Cervantes respecto a su supuesto antivizcaínismo para combatir a quienes veían en el genio de las Letras a un notorio vascófobo ${ }^{51}$. El castellano (que no era un elemento diferenciador) no tenía para los fueristas la dimensión identitaria que tenía el euskera, lengua que les servía para demostrar el mantenimiento de la secular independencia de los vascos y su resistencia a las invasiones extranjeras y además proporcionaba un elemento de unidad entre las provincias vascas. A la par, era considerada un resto vivo de la primitiva lengua de los iberos, de los cuales los vascos serían los últimos directos descendientes, de manera que la lengua vasca expresaba en sí misma la doble identificación vasco-española de los fueristas. No es esta lengua sin embargo un elemento central de su discurso; habría que esperar a la revalorización de la misma que emprendió el movimiento literario del Renacimiento Euskaro en el último tercio del siglo XIX para que adquiriera protagonismo creciente, y a que se desarrollara desde los años ochenta una política de fomento del euskera por parte de las diputa-

49 Ferran Archilés y Manuel Martí, «Un país tan extraño...», pp. 252-253.

50 Carlos Martínez Gorriarán, Casa, Provincia, Rey. Para una historia de la cultura del poder en el País Vasco, Alberdania, Irún, 1993, p.15.

51 Reeditó la obra en 1899 con el título Cervantes vascófilo: refutación de los errores propalados por Pellicer, Clemencín, Fernández Guerra, etc. acerca de la supuesta ojeriza de Cervantes contra la Euskal-erria. 
ciones vascas que revelaba un salto cualitativo en su consideración como patrimonio cultural e identitario que debía ser protegido ${ }^{52}$. Fue entonces cuando los miembros de la Asociación Euskara de Navarra hicieron de la lengua, en vez de los fueros, la base de la identidad del pueblo vasco, su elemento más esencial; la lengua «es la nacionalidad», afirmaron, y cifraron en su conservación la supervivencia del pueblo vasco ${ }^{53}$. Sabino Arana consideró también al euskara la lengua nacional de los vascos, testimonio de la originalidad y pureza de la raza vasca, aunque cifró en esta última la clave de la identidad e hizo del antiespañolismo el elemento central de su discurso ${ }^{54}$.

El País Vasco fue un espacio difícil para la socialización del discurso del nacionalismo liberal español -y difícil no es cerrado-, porque existía otro fuerte discurso identitario en concurrencia, el del fuerismo, que también era un discurso sobre la españolidad de los vascos, pero diferente a aquél. Respondía a las necesidades específicas de la sociedad vasca de aquel tiempo, necesidades que un código identitario como el que definió y socializó el moderantismo no podía satisfacer. Hay que preguntarse por la necesidad histórica de cada discurso, su por qué y para qué. Si la formulación de la nación española respondió a la necesidad de dotar de legitimidad al nuevo orden político, el Estado liberal, el de la identidad vasca fue resultado de la necesidad de ofrecer nuevos y poderosos argumentos a la defensa del mantenimiento de la foralidad en el seno de ese Estado, de legitimar la pervivencia del orden foral - lo que tenía a su vez también, no hay que obviarlo, un fundamental trasfondo de perpetuación del poder de las élites dirigentes - . Esta necesidad obligaba a subrayar la singularidad y diferencia de los vascos respecto al resto de españoles, a no sumergirlos

52 Sobre el Renacimiento Euskaro véase Antonio Elorza, Nacionalismo vasco 18761936. Historia General del País Vasco, vol. 11, Haranburu, San Sebastián, 1981. Sobre la citada política de fomento del euskera véase Coro Rubio, La identidad vasca...

53 «Mientras los vascongados conserven su habla original y privativa, no haya temor de que disminuya el amor a sus envidiados fueros, porque cada palabra que pronuncien les recordará el estado social y político de sus padres, y les alentará a no cejar nunca en la reivindicación legal de sus imprescriptibles derechos». Arturo Campión: «De la conservación de la lengua vascongada», $\mathrm{La} P a z, 25$ de octubre de 1876 .

${ }^{54}$ Sobre el valor otorgado por el nacionalismo vasco al euskera véase Ludger Mees, «Euskara», en Santiago de Pablo et al. (coords.), Diccionario de símbolos del nacionalismo vasco, Tecnos, Madrid, 2012, pp. 320-344. Sobre el sentimiento antiespañol en Arana véase José Luis de la Granja, «El antimaketismo: la visión de Sabino Arana sobre España y los españoles», Norba. Revista de Historia, 19 (2006), pp.191-203; Ídem, «La identidad vasca según Sabino Arana», Grand Place, 3 (2015), pp. 11-18. 
en categorías homogeneizadoras ${ }^{55}$, a presentarlos como una nacionalidad diferenciada dentro de la nación española, para exigir así un tratamiento político diferenciado.

Contenidos distintos, espacios de significación distintos, necesidades distintas. El discurso sobre la identidad vasca del fuerismo no pudo servir por tanto de vehículo de socialización de la idea de nación homogénea del discurso nacionalista del liberalismo moderado; ahora bien, sí ayudó a la socialización de un determinado sentimiento de españolidad, de una determinada idea de España, entendida ésta en los términos explicados más arriba. Como ya he señalado, el vasquismo fuerista fue un regionalismo atípico, por su grado de afirmación del territorio como sujeto activo de derechos y su grado de elaboración de una personalidad etnocultural. Y también se comportó de forma atípica en el papel que los regionalismos jugaron como mecanismo informal de nacionalización española, en el sentido de que a la par que difundió la aceptación del marco nacional, con un contenido específico, socializó la idea de la diferencia y singularidad vasca, su consideración como pueblo y nacionalidad diferenciada dotada de singulares derechos. Todo ello sintetizado en una identidad vasco-española en la que convivían armónicamente ambas identificaciones.

El caso vasco pone de manifiesto que la construcción de la región actúa ciertamente como informal mecanismo nacionalizador, pero también que puede hacerlo, y así fue en este caso, en una doble dirección, abriendo un camino distinto que incluso acabe rompiendo las dobles identificaciones características de aquélla. Y es que debemos entender el regionalismo de forma aún más compleja. El regionalismo vasco socializó sí una adscripción nacional de rango estatal, una identificación con España en la que enraizaría el nacionalismo español presente en el país vasco en los años de la Restauración, pero a la vez una fuerte adscripción regional, con contenido político, un patriotismo vasco, susceptible de transformarse también, con el tiempo y la oportunidad histórica, en otro sentimiento nacionalista, subestatal, incluso excluyente, como el que formularía al final del

55 En otro espacio y contexto, también se articuló sobre la idea de singularidad la imagen de los pastores vascos en el Oeste americano, haciendo de ellos los más capaces, leales y asimilables trabajadores (entre otros, por criterios raciales, whiteness), lo que buscaba también librarles de su homogenización, en este caso con otros inmigrantes, mejicanos especialmente. Lo ha explicado Iker Saitua en Sagebrush Laborers: Basque Immigrants in Nevada's Sheep Industry. International Dimensions and the Making of an Agricultural Workforce, 1880-1954, tesis doctoral, Universidad de Nevada (Reno), abril 2016. 
siglo XIX Sabino Arana. La posibilidad de que esto sucediera solo se abriría una vez que el objetivo del discurso fuerista, la conservación foral, fracasara definitivamente, en 1876-1877, y se inaugurara un tiempo político nuevo. El regionalismo fuerista albergó así potencialidades bien distintas, que una específica oportunidad histórica podía o no desarrollar. Dicho de otro modo, esta construcción de la región actuó también en una dirección diferente y paralela a la de la aceptación del marco estatal, generando un suelo fértil del que se nutriría más tarde el nacionalismo vasco. La doctrina de Sabino Arana, y especialmente su formulación identitaria, no se explican mirando solo al carlismo y al integrismo, considerados principales fuentes del primer nacionalismo vasco, sino también al fuerismo, tanto como discurso político-identitario como proyecto político caducado. El regionalismo vasco ayuda a explicar así tanto el nacionalismo español en el País Vasco finisecular como el nacionalismo vasco; el fuerismo actuó de nutriente (no exclusivo por supuesto) de ambos.

\section{El camino hacia el antiespañolismo aranista}

Esa armónica síntesis entre identidad española y vasca que representó el fuerismo, y que es el elemento que más diferencia su discurso vasquista del que formulará a finales del siglo XIX el nacionalismo aranista, el que lo hace radicalmente distinto, hubo de hacer frente a un notable desafío entre 1869 y 1876 . La legislación anticlerical del Sexenio fue determinante en ello, al extender en el País Vasco la idea de que España se descatolizaba y se alejaba del piadoso oasis que aquél constituía. Y junto a ella, el impacto del desmantelamiento definitivo de los fueros vascos en 18761877. Ese desmantelamiento culminó una destructiva campaña de publicidad para hacerlos responsables de la guerra, que generó en la opinión pública española un sentimiento negativo no solo hacia los fueros sino hacia los vascos, a los que se tildó de montañeses ignorantes y fanáticos, definiendo un nuevo y negativo estereotipo vasco atravesado por el mito del bárbaro ${ }^{56}$. En realidad, esa campaña se había iniciado mucho antes, pues ya en 1839 se había formulado la idea de que los carlistas y las Provincias Vascongadas eran una misma realidad. De ella formaron parte piezas

56 Sobre este mito, Juan M. ${ }^{\text {a }}$ Sánchez Prieto, El imaginario vasco..., p. 411; Fernando Molina, La tierra del martirio..., pp. 165-168. 
como ésta, salida de la pluma de un republicano, F. Ruiz de la Peña, que en un opúsculo publicado en 1874 escribió:

El vasco-navarro vive dentro de nuestro mapa, se cobija bajo nuestra bandera, y como los moradores de todas las otras comarcas nacionales, hace suyas las ventajas de la ciudadanía española. [...] Son súbditos españoles para implorar en sus conflictos el amparo cariñoso de la Madre patria, para lo demás aun peores que extranjeros. [...] Hijos que así se conducen son indignos. [...] En mala hora los prohijó la nación de Pelayo por incitación propia, o por ofrecimiento de aquéllos. La que incitó fue cándida, el que se ofreció fue artero. [...]

Ni algo siquiera tenéis de patriotas. Os oigo hablar de la nación con fría indiferencia, si no con durísimos desdenes. Todo consejo que tienda a despertar en vuestros ánimos sincero desinterés de amor nacional, os irrita. [...]

Hermanas se dicen las tres provincias, pero se niegan a dar ese dictado a las otras. Brindan unas por otras en sus regocijos, rara vez por la Patria, alguna por el ejército, y por nuestras glorias y prosperidades, nunca.

Laurac-bat (cuatro en una) dicen. ¡No!!! Les respondo: somos cuarenta y nueve provincias en una gran provincia, en una gloriosa nacionalidad, llamada ESPAÑA ${ }^{57}$.

Denuncias como ésta generaron un clima de hostilidad manifiesta, un sentimiento antivasco en la opinión pública española. En mayo de 1876 Cánovas advirtió a los comisionados vascongados en Madrid «que el espíritu de la nación está irritado contra la mayoría de los habitantes vascos» ${ }^{58}$, y a las Cortes de aquel año llegaron numerosos telegramas de diputaciones y ayuntamientos españoles solicitando la abolición de los fueros. Cánovas aprovechó entonces para hacer valer una concepción de la unidad constitucional del Estado distinta de la que había triunfado en las Cortes de 1839 - la interpretación Arrázola, que resumía esa unidad en un mismo monarca y Parlamento - y la concretó en la extensión de los mismos derechos y deberes para todos los españoles. Sacó así adelante la

57 F. Ruiz de la Peña, Los Vasco-Navarros ante la España y ante los otros españoles. Tres capítulos y epílogo, León, 1874. Extracto de una cita recogida en Juan M. a Sánchez Prieto, El imaginario vasco..., pp. 805-807.

58 Archivo General de Gipuzkoa, DM. 4-6, acta de las reuniones entre el presidente del Consejo de Ministros y los comisionados vascongados, mayo de 1876. 
Ley de 21 de julio de $1876^{59}$. El sentimiento de frustración que produjo en el País Vasco la que inmediatamente fue denunciada como «ley de castigo» y denominada ley abolitoria, dio lugar a un generalizado clima de exaltación fuerista, una explosión de protestas contra dicha ley y encendidas reclamaciones de reposición foral que se mantuvo varios años. Y en ese tiempo los políticos fueristas alertaron sobre el debilitamiento del sentimiento español que ella iba a causar. El diputado alavés Mateo Benigno Moraza habló así en el Congreso, en mayo de 1877, de las consecuencias que la desaparición de los fueros podían tener para la conservación del sentimiento español: «Por eso venimos a pediros que la deroguéis [la ley de 21 de julio de 1876], porque os creemos a todos muy interesados también en que el país vasco mantenga vivo en el fondo de su alma el sentimiento de monarquismo y de españolismo que tan sincero, verdadero y grande es en él» ${ }^{60}$. En el contexto post-1876, el discurso político de las élites vascas insistió más que nunca en el nexo entre sentimiento español y conservación de los fueros, y en la idea del carácter condicionado de la pertenencia del país a la Corona de Castilla. Fidel Sagarmínaga escribió:

Jamás los vascongados, desde su incorporación a la corona de Castilla, trataron de atentar contra la unidad del Estado. Siempre entendieron renunciada su antigua soberanía absoluta en beneficio de la patria común mientras les fueran reconocidos y conservados los derechos que en orden a la gobernación de la propia tierra les pertenecían. ${ }^{61}$

Desde 1876 el sentimiento español en el País Vasco empezó a experimentar sensibles cambios. Apareció un sentimiento victimista, que más tarde desarrollará hasta sus últimas consecuencias el nacionalismo aranista, y que se expresó en el discurso político en la dualidad opresor/oprimido: «Hoy la inconsciente y extraviada opinión pública hasta la virtud del patriotismo les niega y parece complacerse en despertar en ellas el desamor al opresor que naturalmente se despierta en el corazón del opri-

59 «Los deberes que la Constitución política ha impuesto siempre a todos los españoles de acudir al servicio de las armas cuando la Ley los llame, y de contribuir en proporción de sus haberes a los gastos del Estado, se extenderán, como los derechos constitucionales se extienden, a los habitantes de las provincias de Vizcaya, Guipúzcoa y Álava del mismo modo que a los demás de la Nación».

60 Diario de sesiones de Cortes, Congreso, 8 de mayo de 1877.

${ }^{61}$ Fidel de Sagarmínaga, Memorias históricas de Vizcaya, Imprenta de E. Delmás, Bilbao, 1880 , p. 471. 
mido», se lamentaban las diputaciones forales en una exposición al rey de julio de $1876^{62}$. Un sentimiento que se hizo visible también en la literatura de ficción de la época, la literatura histórico-legendaria vasca:

¿Por qué se nos hace tan cruda guerra? Doloroso es pensarlo, pero diríase que hay empeño en borrar de nuestros corazones el amor que tenemos a España, amor que nuestros padres nos infundieron en la niñez con sus lecciones y con su ejemplo, y que forma, por decirlo así, una parte de nuestro ser. Como españoles y como vascongados deploramos amargamente lo que está sucediendo [...y] quisiéramos ver disminuir, no aumentar, los elementos de discordia hacinados en nuestra patria. ${ }^{63}$

Y junto a ese sentimiento victimista, se inició un proceso de negativación de lo castellano/español que preparó el camino al furibundo antiespañolismo del nacionalismo aranista. Así lo expresó un relato literario de 1881, publicado en un vehículo tan popular como un calendario, firmado por el navarro Arturo Campión, miembro de la Asociación Euskara de Navarra, en la que desde 1878 convergían vasquistas alaveses, guipuzcoanos, vizcaínos y navarros ${ }^{64}$ :

El tren se detenía en la estación. Al mismo tiempo resonó un estruendo espantoso, compuesto de gritos, silbidos, blasfemias, conversaciones, cantos, risotadas, patadas y manotadas; cualquiera hubiese dicho que dentro del tren venía una tribu del Riff.

- ¿Qué es eso?, pregunté.

- Un tren de Ceuta, me contestó el jefe de estación.

Todo lo comprendí; no venían los moros, sino sus hermanos. Madrid vomitaba su populacho sobre Guipúzcoa [...]. Allá iban chulos y chulas a introducir una palabra obscena, a sembrar una blasfemia, a matar una costumbre antigua, a sustituir con otra una prenda de traje indígena, en una palabra, a pasar la fétida esponja de la asimilación sobre los puros

62 Exposición acordada en conferencia foral de las diputaciones de Álava, Guipúzcoa y Vizcaya en julio de 1876 y dirigida al rey Alfonso XII solicitando que negara la sanción real al proyecto de ley de fueros sometido por el Gobierno a la aprobación de las Cortes.

63 Vicente de Arana, Oro y Oropel, Imprenta de Juan E. Delmás, Bilbao, 1876, p. 96.

${ }^{64}$ En su primera nómina de socios honorarios figuraban Mateo Benigno Moraza, Pedro Egaña, Fermín Herrán, Antonio Trueba, Juan E. Delmás, Nicolás de Soraluce, José M. ${ }^{\text {a }}$ Iparraguirre, José Manterola, Juan Venancio Araquistain, Serafín Olave, Ramón Ortiz de Zárate, Fidel Sagarmínaga o Vicente Navarro Villoslada. Juan M. ${ }^{a}$ Sánchez Prieto, El imaginario vasco..., p. 405. 
colores del pueblo euskaro! Esto matará a aquello, decía yo también, fijando los ojos llorosos en mi caserío de Zelayarán ${ }^{65}$.

Léon de Rosny, un destacado etnólogo francés experto en lenguas orientales, reparó en ese sentimiento antiespañol cuando en los años ochenta del siglo XIX visitó el País Vasco. Relató en su libro de viaje publicado en París en 1889 Taureaux et mantilles: souvenirs d'un voyage en Espagne et en Portugal, que al dirigirse a una muchacha vasca y decirle «par mégarde, qu'elle était Espagnole», ésta le respondió molesta: «Je croyais vous avoir appris que j'étais Basquaise: il n'y a pas d' Espagnols dans ma famille» ${ }^{66}$. Rosny concluía: «Un Espagnol, c'était pour elle un étranger: les Castilles ne sont pas son pays», pero igualmente indicaba que había tratado de indagar en qué medida «les Basques avaient le sentiment de leur autonomie» y había llegado a esta conclusión: «Ce sentiment m'a paru faible; néamoins il existe. Il existe à l'état latent, je le veux bien, mais d'une façon qui laisse penser qu'il faudrait peu de choses pour lui donner vigueur et avenir».

No hay que extremar sin embargo los términos sobre la aparición de este sentimiento antiespañol, detectable ya desde finales de los años setenta. La identidad española siguió manteniéndose viva en amplias capas de la población, incluso entre acérrimos fueristas. Uno de los principales protagonistas de la exaltación fuerista post1876, el grupo de los euskalerriacos, fueristas intransigentes organizados en torno a la Sociedad Euskalerria de Bilbao y liderados por Fidel Sagarmínaga — sociedad de la que también formó parte el naviero vizcaíno Ramón de la Sota, que en 1898 ingresaría en el PNV encarnando su corriente moderada y autonomista, así como el nexo físico entre fuerismo y nacionalismo - , siguió defendiendo la identidad española de los vascos. Según Sagarmínaga, «los vascongados no han sido nunca otra cosa que españoles, y aquellos entre los españoles que más originalidad y pureza en su españolismo tuvieran», y añadióo ${ }^{67}$ :

65 Calendario vasco-navarro especial para las cuatro provincias hermanas, revisada la parte litúrgica por el pbro. doctor D. Estanislao Jaime de Labayru, la astronómica por el zaragozano D. Joaquín Yagüe y la literaria dirigida por el archivero y cronista del Señorío de Vizcaya D. Antonio de Trueba y colaborada por casi todos los escritores vasconavarros y otros, Imprenta de Cristóbal Pérez, Bilbao, 1881, cfr. pp. 107-117.

${ }^{66}$ Léon de Rosny, Taureaux et mantilles: souvenirs d'un voyage en Espagne et en Portugal, Paul Ollendorff éditeur, París, 1889, p. 33. La obra fue reeditada con posterioridad.

${ }^{67}$ Fidel de Sagarmínaga, Memorias históricas de Vizcaya..., p. 187 y 474. 
Podrá decirse de nosotros que aspiramos a ser un país semi-independiente, dentro de la nación española y que defendemos cierta diversidad de circunstancias políticas, contraria a la unidad del Estado, según la constitucional la establece; pero las constituciones se reforman cuando se quiere, sino se abrogan «in totum»; nuestra supuesta independencia no ha comprometido nunca la de España [...] y la unidad del Estado es cosa convencional que, a la verdad, puede entenderse y se ha entendido de modo muy distinto en la antigüedad y en la edad moderna, en América y en Europa.

Su llamamiento a la unidad vasconavarra para luchar por la reintegración de los fueros hablaba de «formar un solo pueblo, dentro de la patria común española». A pesar de ello, su fuerismo intransigente fue acusado de separatista. El diario La Unión Vasco Navarra, órgano de los euskalerriacos, denunciaba en 1880 que los liberales «de disparate en disparate han concluido por llamarnos separatistas» ${ }^{68}$. Otro tanto hacían los euskaros navarros en similares fechas, esforzándose ambos en demostrar que no lo eran. Pero las acusaciones de separatismo alcanzaron no sólo a euskaros y euskalerriacos: en noviembre de 1881 Castelar protestaba contra un discurso del entonces diputado carlista (y antiguo fuerista) Ramón Ortiz de Zárate «porque en el fondo de ese discurso, que es el vivo reflejo de la opinión de las Provincias Vascongadas [...] late el espíritu separatista, mucho más funesto y terrible que el filibustero» ${ }^{69}$.

El fantasma del «peligro separatista» se fue incrementando desde entonces en la opinión pública española, espoleado por la irrupción de los nacionalismos subestatales, y durante la coyuntura noventayochista actuaría como revulsivo del nacionalismo español. Cuando el nacionalismo vasco dejó oír por primera vez su voz en la Sanrocada de Guernica de 13 de agosto de 1893 lo hizo con un provocador «iMuera España!», pronunciado en el momento de los brindis por uno de los pocos nacionalistas que asistían al banquete de homenaje que carlistas y fueristas organizaron en esta villa para el Orfeón Pamplonés. En 1895 Sabino Arana escribió en Bizkaitarra, órgano de prensa con el que iniciaría la propagación de su doctrina, que los vascos no eran españoles, pues aunque «parezcan españoles, por regirse por las leyes españolas y estar gobernados por el poder

${ }^{68}$ La Unión Vasco Navarra, n. ${ }^{\circ} 122,5$ de diciembre de 1880. Citado por Javier Corcuera, Orígenes, ideología y organización del nacionalismo vasco, 1876-1904, Siglo XXI, Madrid, 1979, p. 129.

${ }_{69}$ Citado por J. Corcuera, Orígenes..., p. 129. 
español, esto nada significa si, tomando la historia en las manos, resulta que están así contra su propia naturaleza. En una palabra [...] los bizkainos no son españoles por naturaleza, aunque lo sean hoy de hecho y por fuerza $\gg^{70}$. Por esas mismas fechas la gran burguesía industrial vizcaína, continuando una línea abierta en los años treinta por la burguesía mercantil de la ciudad de San Sebastián, identificaba sus intereses con los estatales, y reclamaba un proteccionismo bajo el lema «España para los españoles»: nacionalismo económico español. Por aquella época también, el primer socialismo vasco se configuraba como antinacionalista vasco y españolista, pero a la vez antipatriótico y antinacionalista español, y escasamente vasquista - a excepción del socialismo eibarrés $-{ }^{71}$. El paisaje identitario vasco se hacía más complejo.

70 «Qué somos?», Bizkaitarra, 16 de junio de 1895.

71 Véase Antonio Rivera, Señas de identidad. Izquierda obrera y nación en el País Vasco, 1880-1923, Biblioteca Nueva, Madrid, 2003, cfr. pp. 100, 147, 148 y 202. 